\title{
A systematic review of survival following anti-cancer treatment for small cell lung cancer
}

Abstract word count: 298

Word count: 2,960

Corresponding author:

1) Dr Gavin S Jones, BMBS

Division of Epidemiology and Public Health, University of Nottingham, UK, NG5 1PB

Gavin.jones@nottingham.ac.uk

No conflict of interest

\section{2) Dr Kelly Elimian, PhD}

Division of Epidemiology and Public Health, University of Nottingham, UK, NG5 1PB

Kelly.elimian@nottingham.ac.uk

No conflict of interest

\section{3) Prof David R Baldwin, MD}

Division of Epidemiology and Public Health, University of Nottingham Department of Respiratory medicine, Nottingham University Hospitals David.baldwin@nottingham.ac.uk

No conflict of interest

4) Prof Richard Hubbard, MD

Division of Epidemiology and Public Health, University of Nottingham

Richard.hubbard@nottingham.ac.uk

No conflict of interest

\section{5) Prof Tricia M McKeever, PhD}

Division of Epidemiology and Public Health, University of Nottingham

Tricia.mckeever@nottingham.ac.uk

No conflict of interest

Funding: Roy Castle Lung cancer foundation (2015 14 Hubbard) and University of Nottingham John Turland fund

Prospero protocol ID: CRD42016037772.

Summary Message: This is a comprehensive analysis of early and late survival following treatments recommended by the European Society of Medical Oncology for small cell lung cancer. Our survival benchmarks can inform the treatment selection process going forward. 
Abbreviations

SCLC- Small cell lung cancer

ESMO- European Society of Medical Oncology

PCI- Prophylactic cranial irradiation

LD-SCLC- Limited stage small cell lung cancer

RCT- Randomized controlled trial

ED-SCLC- Extensive stage small cell lung cancer

PS- Performance status

$\mathrm{Cl}$ - Confidence interval 


\section{Abstract \\ Objectives}

We conducted a systematic review and meta-analysis of survival following treatment recommended by the European Society of Medical Oncology for SCLC in order to determine a benchmark for novel therapies to be compared with.

\section{Materials and Methods}

Randomized controlled trials and observational studies reporting overall survival following chemotherapy for SCLC were included. We calculated survival at 30 and 90-days along with 1-year, 2-year and median.

\section{Results}

We identified 160 for inclusion. There were minimal 30-day deaths. Survival was $99 \%(95 \% \mathrm{Cl} 98.0$ $\left.99.0 \%, I^{2} 33.9 \%, \mathrm{n}=77\right)$ and $90 \%\left(95 \% \mathrm{Cl} 89.0-92.0 \%, \mathrm{I}^{2} 79.5 \%, \mathrm{n}=73\right)$ at 90 days for limited (LD-SCLC) and extensive stage (ED-SCLC) respectively.

The median survival for LD-SCLC was 18.1 months $\left(95 \% \mathrm{Cl} 17.0-19.1 \%, \mathrm{I}^{2} 77.3 \%, \mathrm{n}=110\right)$ and early thoracic radiotherapy (thoracic radiotherapy 18.4 months $\left(95 \% \mathrm{Cl} 17.3-19.5, \mathrm{I}^{2} 78.4 \%, \mathrm{n}=100\right)$ ) vs no radiotherapy 11.7 months $(95 \% \mathrm{Cl} 9.1-14.3, \mathrm{n}=10)$, prophylactic cranial irradiation ( $\mathrm{PCl} 19.7$ months vs No $\mathrm{PCl} 13.0$ months $\left(95 \% \mathrm{Cl} 18.5-21.0, \mathrm{I}^{2} 75.7 \%, \mathrm{n}=78\right.$ and $95 \% \mathrm{Cl} 10.5-16.6, \mathrm{I}^{2} 81.1 \%, \mathrm{n}=15$ respectively)) and better performance status (PSO-1 22.5 months vs PSO-4 15.3 months $(95 \% \mathrm{Cl} 18.7$ 26.1, $\mathrm{I}^{2} 72.4 \%, \mathrm{n}=11$ and $\left.\left.95 \% \mathrm{Cl} 11.5-19.1 \mathrm{I}^{2} 77.9 \%, \mathrm{n}=13\right)\right)$ augmented this. For ED-SCLC the median survival was 9.6 months $\left(95 \% \mathrm{Cl} 8.9-10.3 \%, \mathrm{I}^{2} 95.2 \%, \mathrm{n}=103\right)$ and this improved when irinotecan+cisplatin was used, however studies that used this combination were mostly conducted in Asian populations where survival was better. Survival was not improved with the addition of thoracic radiotherapy or $\mathrm{PCl}$. 
Survival for both stages of cancer was better in modern studies and Asian cohorts. It was poorer for studies administering carboplatin+etoposide but this regimen was used in studies that had fewer patient selection criteria.

\section{Conclusion}

Early thoracic radiotherapy and PCI should be offered to people with LD-SCLC in accordance with guideline recommendations. The benefit of the aforementioned therapies to treat ED-SCLC and the use of chemotherapy in people with poor PS is less clear.

Keywords

Epidemiology

SCLC survival

Chemotherapy

Radiotherapy

30-day survival 


\section{Introduction}

The European Society of Medical Oncology (ESMO) recommend 4-6 cycles of cisplatin or carboplatin doublet chemotherapy as first-line treatment for all stages of SCLC.(1) Thoracic radiotherapy can be given concurrently, in fitter individuals with limited stage (LD-SCLC), or sequentially to people who have responded to initial chemotherapy. Prophylactic cranial irradiation $(\mathrm{PCl})$ is generally reserved for people who have responded to chemotherapy. These treatments have remained unchanged for 30 years but novel therapies are emerging. Immunotherapies such as atezolizumab (IMPOWER-133 trial) and durvalumab (CASPIAN), in combination with chemotherapy, have shown increases in the median survival of approximately 2 and 3 months respectively when compared to chemotherapy alone. $(2,3)$ Both these treatments have been given approval for use in extensive stage SCLC (EDSCLC) by the US Food and Drug Administration. However, these new treatments are expensive and the U.K. list price for one vial of atezolizumab is approximately $£ 3,800 .(4)$ Hence, in order to assess whether these novel treatments are economically viable a comprehensive survival assessment of the existing therapies is needed. This will ensure that the claimed survival advantages of immunotherapy are accurate.

Similarly, in order to maximise the efficacy of current treatments patients must be selected appropriately. Deaths occurring early after chemotherapy (within 30-days) are a measure of poor selection, but the evidence base for this in SCLC is limited.(5) Hence, the objectives of this study are to examine early and late survival by ESMO recommended treatments for SCLC in order to increase this evidence base and inform the appraisal process of novel treatments.

\section{Methods}

\section{Search strategy}

We searched EMBASE, MEDLINE and electronic search engines for English language randomized controlled trials (RCTs) or observational cohort studies which reported overall survival following 
receipt of cisplatin or carboplatin in combination with etoposide, irinotecan or topotecan for SCLC. The search strategy can be found in Supplement 1. Our search was conducted on $7^{\text {th }}$ June 2016. After the initial search we examined the archives of the European Society of Medical Oncology, American Society of Clinical Oncology and the International Association for the Study of Lung Cancer for conference abstracts. We searched the references of included manuscripts. The search was completed on the $22^{\text {nd }}$ November 2017.

\section{Inclusion Criteria}

The inclusion criteria are presented in Supplement 2 and were applied based on the study protocol published in the manuscript. We examined overall survival in treatment naïve individuals with SCLC who received platinum based chemotherapy in-keeping with ESMO guidelines.(1) Studies were excluded if "up front" prophylactic growth colony stimulating-factor or antibiotics were given before the first chemotherapy cycle as these are not routinely recommended in SCLC in the U.K.(6) If a study protocol was changed throughout its duration and this was not compatible with our inclusion criteria it was excluded. Abstract only publications were included. Manuscripts with duplicate study populations were used once, with the most up to date publication being included. Two reviewers (GJ, TM) applied the inclusion criteria, if there was disagreement a third was consulted (DRB or RBH) and a consensus was reached.

\section{Data extraction}

Three reviewers extracted data (GJ, KE, TM) consisting of trial design, participant characteristics, treatment schedule, survival (30-day, 90-day, 1-year, 2-year and median survival), cause of 30-day death and quality score. We used graph digitalizer software, Digitizelt V2.2, (Braunschweig, Germany) to extract survival data from Kaplan Meier plots if survival data was not within the text.(79) Extracted values were crosschecked for accuracy. Our quality score combined the Cochrane risk of bias and Newcastle-Ottawa scoring methods (found in Supplement 3) to assess survival reporting and study design. RCTs and cohort studies could achieve a maximum score of 30 and 27 respectively. 


\section{Statistical Analysis}

All analyses were carried out using STATA V15 (TX, USA). We derived pooled survival estimates from individual treatment arms. For example, a study with two treatment regimens meeting our inclusion criteria would have two survival outcomes in our meta-analysis. We calculated a pooled survival estimate at: 30-days, 90-days, 1-year and 2-years using a random effects model allowing for Freeman-Tukey arcsine transformation to stabilize variances between studies.(10) The median survival estimate was produced from a random effects inverse-variance method (DerSimonian Laird).(11) Heterogeneity was quantified using the $I^{2}$ statistic.(12) In studies where the median survival was presented without $95 \%$ confidence intervals $(\mathrm{Cl})$, we used a method by R.P Jones et al to estimate variance and $95 \% \mathrm{Cls}$.(13) We conducted a sensitivity analysis without these estimated values.

Combined stage, LS-SCLC and ED-SCLC pooled survival estimates (with $95 \% \mathrm{Cls}$ ) were presented separately. Estimates were stratified by study factors and interventions. Studies were grouped by quality score; (poor (0-9), moderate (10-14), good (15-19) and very good (20-27)). Study design was classed as RCT or cohort. The study year and median participant age were divided into 10-year groups. The study region was the continent where it was conducted and broadly represents the ethnicity of the cohort. Performance status (PS) was derived from inclusion criteria and divided into 0-1 to 0-4. Mixed/alternating chemotherapy regimens were grouped into: platinum+etoposide (cisplatin/carboplatin+etoposide) and platinum+etoposide/irinotecan (cisplatin/carboplatin+etoposide/irinotecan). Thoracic radiotherapy, if given, was grouped according to the start time (before (early) or after (late) the third chemotherapy cycle). 


\section{Results}

\section{Search process}

We identified 10,487 titles and after screening 130 remained. Another 30 studies were identified from references of included manuscripts giving a total of 160 studies. Figure 1 is a flowchart of this process.

\section{Summary of studies}

In total, we examined survival data from 22,528 people. Supplement 4 summarises the included manuscripts, 11 of which were abstracts.(14-174) The majority of manuscripts were observational cohort studies (100 (62.5\%)) and the remaining were randomized/non-randomized controlled trials (60 (37.5\%). The earliest commenced in 1981, however, most were from 2000-2009 (67(41.9\%)). Many studies were from Asia (60 (37.5\%)) followed by Europe (45 (28.1 \%)) and North America (36 (22.5\%)). The average, median participant age was 63 years (SD 5.3 years) and most were male (median proportion 78.9\%). Studies mainly consisted of people with PS 0-2 (107 (66.9\%)) and 31 (19.4\%) had minimum life expectancy criterion ranging from $>8$ weeks to $>6$ months. Other inclusion pre-requisites were adequate bone marrow, hepatic and renal function. Common exclusion criteria were pleural/pericardial effusions, cardiovascular disease and symptomatic brain metastases.

The median quality score for cohort studies was $18.5 / 27$ (IQR 15.5-20.5, range 7.5 to $24(34,145)$ ) and $18.5 / 30$ (IQR $17.25-19.75$, range 10 to $19(112,148)$ ) for RCTs. The causes for poorer quality were lack of reporting of early survival and cause of early death.

\section{Thirty day survival}

The 30 -day survival for LD-SCLC studies was $100 \%\left(95 \% \mathrm{Cl} 100 \%, \mathrm{I}^{2} 0 \%, \mathrm{n}=76\right)$ and for ED-SCLC it was $96 \%\left(95 \% \mathrm{Cl} 95-97 \%, \mathrm{I}^{2} 67.3 \%, \mathrm{n}=71\right)$. These varied minimally by study factors and are reported in Supplement 5. We identified 31 studies where 75 people died within 30 days of chemotherapy and the cause of death was published (summarized in Supplements $6 \&$ 7.) The majority of deaths were 
attributed to neutropenic sepsis $(n=27 \quad(36.0 \%))$, disease progression $(n=11 \quad(14.7 \%))$ and cardiovascular, gastrointestinal and others ( $n=8(10.7 \%)$ in each).

\section{Ninety day survival}

Table 1 demonstrates survival at 90 days stratified by study factors. Survival was $99 \%(95 \% \mathrm{Cl} 98$ -

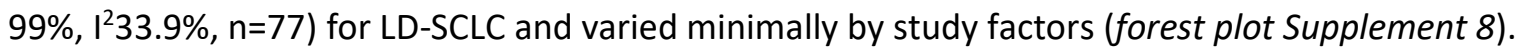

Survival was shorter in ED-SCLC $\left(90 \%\left(95 \% \mathrm{Cl} 89-92 \%, 1^{2} 79.5 \%, n=73\right.\right.$, forest plot Supplement 9). Survival improved in recent studies (2010-2015 96\% $\left.\left(95 \% \mathrm{Cl} 89-99 \%, \mathrm{I}^{2} 81.6 \%, \mathrm{n}=7\right)\right)$ and in Asian cohorts $\left(97 \%\left(95 \% \mathrm{Cl} 95-98 \%, \mathrm{I}^{2} 42.8 \%, \mathrm{n}=26\right)\right)$. Carboplatin+etoposide and cisplatin+topotecan had the poorest 90 -day survival $\left(88 \%\left(95 \% \mathrm{Cl} 83-92 \%, \mathrm{I}^{2} 77.3 \%, \mathrm{n}=14\right)\right.$ and $86 \%\left(95 \% \mathrm{Cl} 83-89 \%, \mathrm{I}^{2} 27.9 \%\right.$, $\mathrm{n}=35)$ respectively). Worse PS heralded lower 90 -day survival (PS 0-4 $87 \%\left(95 \% \mathrm{Cl} 74-96 \%, \mathrm{I}^{2} 92.7 \%\right.$, $n=9))$.

\section{Late survival}

We report late survival at 1-year (demonstrated in Table 2) and this varied considerably by stage. The 1-year survival for LD-SCLC was $73 \%\left(95 \% \mathrm{CI} 70-75 \%, I^{2} 74.0 \%, n=91\right.$, forest plot Supplement 10$)$. This was better with Asian cohorts $\left(79 \% \quad\left(95 \% \mathrm{Cl} 75-82 \%, 1^{2} 60.9 \%, \mathrm{n}=37\right)\right)$, receipt of irinotecan+etoposide $\left(77 \%\left(95 \% \mathrm{Cl} 66-86 \%, \mathrm{I}^{2} 62.6 \%, \mathrm{n}=7\right)\right.$, young age $\left(74 \%\left(95 \% \mathrm{Cl} 69-79, \mathrm{I}^{2} 61.7 \%\right.\right.$, $\mathrm{n}=20))$, early thoracic radiotherapy $\left(77 \%\left(95 \% \mathrm{Cl} 73-80 \%, \mathrm{I}^{2} 68.0 \%, \mathrm{n}=40\right)\right.$ and $\mathrm{PCI}(75 \%(95 \% \mathrm{Cl} 72-$ $\left.\left.77 \%, I^{2} 74.1 \%, n=69\right)\right)$.

One-year survival for ED-SCLC was $38 \%\left(95 \% \mathrm{Cl} 35-40 \%, \mathrm{I}^{2} 74.9 \%, \mathrm{n}=80\right.$, forest plot Supplement 11$)$. This has improved with time $\left(2010-201555 \%\left(95 \% \mathrm{Cl} 43-68 \%, \mathrm{I}^{2} 83.9 \%, \mathrm{n}=7\right)\right.$ vs $1980-198928 \%$ $\left.\left(95 \% \mathrm{Cl} 24-33 \%, \mathrm{I}^{2} 45.4 \%, \mathrm{n}=15\right)\right)$. In addition, Asian cohorts $\left(47 \%\left(95 \% \mathrm{Cl} 42-52, \mathrm{I}^{2} 72.9 \%, \mathrm{n}=31\right)\right)$ and irinotecan+cisplatin $\left(49 \%\left(95 \% \mathrm{Cl} 43-54 \%, 1^{2} 70.6 \%, \mathrm{n}=15\right)\right)$ had better survival. Survival was not significantly different with age, PS or with the addition of thoracic radiotherapy and $\mathrm{PCl}$. 
The 2-year survival for LD-SCLC was $41 \%\left(95 \% \mathrm{Cl} 38-44 \%, \mathrm{I}^{2} 78.9 \%, \mathrm{n}=85\right)$ and for ED-SCLC it was $9 \%$ $\left(95 \% \mathrm{Cl} 7-10 \%, \mathrm{I}^{2} 67.5 \%, \mathrm{n}=66\right)$. On the whole, there was significant variation in survival by the same study factors as those at 1-year. Hence, we have not presented these results in full. The table of results can be found in Supplement 12 .

\section{Median survival}

The results of median survival are shown in Table 3. For LD-SCLC survival was 18.0 months $(95 \% \mathrm{Cl}$ 17.0-19.1, ${ }^{2} 77.3 \%, \mathrm{n}=110$ (forest plot Supplement 13 )). This was longer with modern studies, Asian cohorts, better PS, young age, receipt of thoracic radiotherapy and $\mathrm{PCl}$.

For ED-SCLC median survival was 9.6 months $\left(95 \% \mathrm{Cl}\right.$ 8.9-10.3, $\mathrm{I}^{2} 95.2 \%, \mathrm{n}=103$ (forest plot Supplement 14)). This was better for studies that gave irinotecan+etoposide, had Asian cohorts and included people with good PS.

The aforementioned results showed significant heterogeneity and this was not reduced by the sensitivity analysis (studies with estimated $95 \% \mathrm{Cls}$ removed) however, the conclusions remained the same.

\section{Discussion}

\section{Main Findings}

There were few deaths within the 30 days of the first chemotherapy dose and these were predominantly due to neutropenic sepsis. Early survival was similar across all ages but this changed at 1-year for LD-SCLC, where the elderly were less likely to survive, most likely a result of attrition bias. Long term survival varied considerably by stage and was better in Asian cohorts and recent studies that included people with good PS. Thoracic radiotherapy and $\mathrm{PCl}$ augmented median survival in LD-SCLC. 


\section{Strengths}

To our knowledge, this is the largest systematic review conducted in SCLC. Quantifying early and late survival permits a better understanding of the early mortality risks of treatment vs the long-term survival gains, allowing better informed treatment choices and patient selection. The large number of included studies means our results are less prone to publication bias unlike other, smaller, systematic reviews.(175-177)

\section{Limitations}

In this study some factors, such as $\mathrm{PCl}$ and radiotherapy, do not consist of all the individuals who received these treatments as we categorised this variable from the study protocol. This grouping method was needed as there was significant heterogeneity in study design and reporting. However, our results are consistent with other literature. Our results do not fully represent "real world survival" as many patients in clinical practice do not meet trial inclusion criteria. However, we have included observational studies that have far less selection criteria than RCTs.

\section{Comparisons with other research}

\section{Early survival}

The evidence base for early mortality and its causes following chemotherapy is limited. The proportion of treatment related deaths, defined as death related to and within 4 weeks of completion of chemotherapy, was found to be $2.95 \%$ in a systematic review of phase III SCLC trials.(178) Neutropenic sepsis was found to be the leading cause of these. Conversely, observational research from England found that 30-day mortality for palliative and curative chemotherapy for SCLC was $12 \%$ and $4 \%$ respectively.(5) Our findings lie between these two studies as we have included clinical trials and observational studies. 


\section{Chemotherapy and cohort ethnicity}

Irinotecan+cisplatin tended to have better survival in comparison to cisplatin/carboplatin+etoposide and there are several explanations for this. First, carboplatin+etoposide regimens were more commonly used in studies that recruited patients with worse PS and more comorbidities, biasing carboplatin to poorer outcomes. Indeed, when the efficacy of cisplatin and carboplatin were compared in a systematic review of individual patient data there was no difference between the two (median overall survival 9.6 months and 9.4 months for cisplatin and carboplatin respectively). (179) Second, the majority of irinotecan containing studies have been conducted in Asia where it has more favourable outcomes.(175) However, outside of Asia there is limited evidence for its superiority over etoposide.(180) Indeed, a systematic review that included many of the same Asian, irinotecan studies as ours concluded that irinotecan augmented survival by 1-2 months compared to platinum+etoposide.(175) Contrastingly, a study in Caucasians found no differences in survival between etoposide and irinotecan containing chemotherapy.(180) The variation of irinotecan metabolism between ethnic groups is well documented and approximately $10 \%$ of Caucasians have a variant form of the UDP-glucuronosyltransferase 1 polypeptide A1 enzyme. This variant enzyme leads to poorer metabolism and subsequently irinotecan toxicity.(181) (182)

The prevalence of SCLC amongst never-smokers is greatest in Asia and the augmented survival of Asian cohorts is likely a reflection of different SCLC aetiological exposures.(183) Indeed, evidence suggests that never-smokers with SCLC have better survival than ever-smokers. $(184,185)$ This observation is most pronounced in Asian females who have greater exposure to indoor air pollution from cooking oils rather than tobacco.(186) Similarly, genetic analysis of SCLC histological samples from never-smokers have shown a greater burden of oncogene driver mutations (such as EGFR) than in ever-smokers raising the concept of SCLC in never smokers being a distinct disease.(185) Other confounders to our findings are the study design and inclusion criteria. 


\section{Study year}

We found survival was shorter in older studies. Schabath et al drew similar conclusions when they compared the survival of two cohorts of people with SCLC treated at a single centre between 19861999 and 2000-2008.(187) The median overall survival was significantly better in the 2000-2008 cohort (11.3 months $(95 \% \mathrm{Cl} 10.5-12.7)$ ) in comparison to the $1986-1999$ group (15.2 months (95\% Cl 13.6-16.6)). This increase was attributed to greater use of multi-modality therapy rather than chemotherapy alone and less use of cyclophosphamide, doxorubicin and vincristine combination treatment. In addition, the better selection of patients and improved healthcare practices e.g. infection control awareness, also explain our results. $(25,28,41)(46,142,166,167)(188)$. Lastly, improved methods for early detection and staging have caused a modest stage migration over time. This migration towards earlier stage subsequently improves overall survival, the so-called Will Rogers phenomenon. Indeed, the aforementioned study had greater proportions of LD-SCLC during 2000-2008 (50.3\%) in comparison to $1986-1999(40.0 \%)$.

\section{Thoracic radiotherapy}

In-keeping with treatment recommendations, early radiotherapy in LD-SCLC augmented survival. A seminal meta-analysis of 7 RCTs demonstrated improvement in 2 and 3 year survival with thoracic radiotherapy if given within 9 weeks of chemotherapy.(189) Other meta-analyses have found that early radiotherapy increases survival but causes more side effects e.g. severe oesophagitis. $(190,191)$

\section{Prophylactic cranial irradiation}

Our findings align with a systematic review by Aupérin et al that demonstrated prolonged overall survival with PCI for LD-SCLC.(192) Conversely, we found that PCI did not augment survival for EDSCLC, similar to a finding by Takahashi et al.(193) In their study people with ED-SCLC who had responded to chemotherapy were randomized to either; surveillance magnetic resonance imaging of the brain (3-monthly for 12 months then scans at 18 and 24 months after enrolment) or PCl. The study was terminated early as it was clear that PCl was not beneficial to survival. This finding, in 
conjunction with our study, provides strong evidence that, for the most part, PCI in ED-SCLC has a limited role.

\section{Relevance to practice and guidelines}

The European Society of Medical Oncology SCLC clinical practice guideline was published in 2013 and therefore new data are not incorporated. However, Table 4 compares our conclusions with these recommendations and generally supports these. In particular, early thoracic radiotherapy and $\mathrm{PCl}$ for LD-SCLC and the cautious use of chemo-radiotherapy for people with worse PS. In contrast age, which is currently cited as a criterion for choosing cisplatin+etoposide, was not associated with poorer survival, especially in ED-SCLC. The European recommendations contain minimal information about appropriate patient selection and this can cause variation in chemotherapy administration, which is known to occur nationally.(194) Our study could reduce this variation as it quantifies survival so that better informed treatment decisions can be made. Similarly, it can assist with the appraisal of novel therapies as it is a comprehensive survival reference for current treatments.

On the whole, recommended treatments for SCLC have remained unchanged for years when compared to NSCLC. This has reinforced the nihilistic connotations associated with SCLC. We have shown that survival has improved over time in SCLC; a finding which can raise optimism for the future.

\section{Future directions}

An updated version of the ESMO recommendations is expected to be published within the next year and will reflect some of the newer developments in SCLC, particularly immunotherapy and $\mathrm{PCI}$ for ED-SCLC. In addition to immunotherapy other classes of drugs such as RNA polymerase II inhibitors have shown promising results in phase II clinical trials and may become available for patients with relapsed SCLC in the future.(195) Similarly, clinical trials, such as the ADRIATIC trial (NCT03703297) are exploring whether combination immunotherapy can improve survival following concurrent chemo-radiotherapy in LD-SCLC. 


\section{Conclusions}

We have conducted the largest systematic review and meta-analysis of survival in SCLC. Our findings support ESMO recommendations, in particular, early thoracic radiotherapy and PCI for LD-SCLC with the cautious use of chemotherapy for people with worse PS. Cisplatin and carboplatin are preferred, however, we found significant disparities in their long-term survival by ethnicity. This may relate to altered drug metabolism and the differing aetiological exposures for SCLC across ethnic groups.

At present, early mortality risk is not included in the criteria for chemotherapy administration but it is a metric that can inform patient selection. Early mortality risk does not increase for the elderly and age should be cited cautiously as a selection factor. There is great optimism surrounding immunotherapy as it has the potential to revolutionise prognosis in SCLC. Importantly, our research sets a reference point for survival following current treatments to which the success of immunotherapies can be measured.

\section{Acknowledgments}

Gavin Jones: Designed the systematic review as well as search strategy, data extraction, metaanalysis and write up of manuscript. Dr Jones is the Guarantor.

Kelly Elimian: screened manuscripts and extracted data for the meta-analysis

David Baldwin: Designed the study, assisted with writing and interpretation of findings.

Richard Hubbard: Designed the study, assisted writing and interpretation of findings

Tricia McKeever: Designed the study, assisted developing search strategy, screening, data extraction, writing and provided statistical support for meta-analysis.

This study was funded by Roy Castle Lung cancer foundation (grant number 201514 Hubbard) and the University of Nottingham John Turland fund. 
Figure legend

Figure 1: PRISMA flow diagram of the initial electronic search and screening of abstracts and manuscripts. 
1. Früh M, De Ruysscher D, Popat S, Crinò L, Peters S, Felip E. Small-cell lung cancer (SCLC): ESMO Clinical Practice Guidelines for diagnosis, treatment and follow-up†. Annals of Oncology. 2013;24(suppl_6):vi99-vi105.

2. Horn L, Mansfield AS, Szczęsna A, Havel L, Krzakowski M, Hochmair MJ, et al. First-Line Atezolizumab plus Chemotherapy in Extensive-Stage Small-Cell Lung Cancer. New England Journal of Medicine. 2018;379(23):2220-9.

3. Paz-Ares L, Dvorkin M, Chen Y, Reinmuth N, Hotta K, Trukhin D, et al. Durvalumab plus platinum-etoposide versus platinum-etoposide in first-line treatment of extensive-stage small-cell lung cancer (CASPIAN): a randomised, controlled, open-label, phase 3 trial. The Lancet. 2019;394(10212):1929-39.

4. British national formulary- Atezolizumab.

5. Wallington M, Saxon EB, Bomb M, Smittenaar R, Wickenden M, McPhail S, et al. 30-day mortality after systemic anticancer treatment for breast and lung cancer in England: a population-based, observational study. The Lancet Oncology.17(9):1203-16.

6. Crawford J, Caserta C, Roila F, On behalf of the EGWG. Hematopoietic growth factors: ESMO Clinical Practice Guidelines for the applications. Annals of Oncology. 2010;21(suppl_5):v248-v51.

7. Guyot P, Ades A, Ouwens MJ, Welton NJ. Enhanced secondary analysis of survival data: reconstructing the data from published Kaplan-Meier survival curves. BMC Medical Research Methodology. 2012;12(1):9.

8. Phan K, Tian DH, Cao C, Black D, Yan TD. Systematic review and meta-analysis: techniques and a guide for the academic surgeon. Annals of Cardiothoracic Surgery. 2015;4(2):112-22.

9. Dequen $P$, Lorigan P, Jansen JP, van Baardewijk M, Ouwens MJNM, Kotapati S. Systematic Review and Network Meta-Analysis of Overall Survival Comparing $3 \mathrm{mg} / \mathrm{kg}$ Ipilimumab With Alternative Therapies in the Management of Pretreated Patients With Unresectable Stage III or IV Melanoma. The Oncologist. 2012;17(11):137685.

10. Freeman MF TJ. Transformations related to the angular and the square root. The Annals of mathematical statistics. 1950;21:607-11.

11. DerSimonian R, Laird N. Meta-analysis in clinical trials. Controlled clinical trials. 1986;7(3):177-88.

12. Higgins JPT, Thompson SG, Deeks JJ, Altman DG. Measuring inconsistency in meta-analyses. BMJ (Clinical research ed). 2003;327(7414):557-60.

13. Jones RP, Jackson R, Dunne DF, Malik HZ, Fenwick SW, Poston GJ, et al. Systematic review and meta-analysis of follow-up after hepatectomy for colorectal liver metastases. The British journal of surgery. 2012;99(4):477-86.

14. Abdelwahab S, Abdulla H, Azmy A, Abdelfatah A, Abdel-Aziz H, Margerges $\mathrm{M}$, et al. Integration of irinotecan and cisplatin with early concurrent conventional radiotherapy for limited-disease SCLC (LD-SCLC). International Journal of Clinical Oncology. 2009;14(3):230-6.

15. Abdelwahab S, Elghamry W, Azmy A, Elsayed FZ. Accelerated hypofractionated radiotherapy and concurrent etoposide/ cisplatin in patients with limited disease SCLC Journal of thoracic oncology. 2015;10(9):S626-S.

16. Akyurek S, Onal C, Cagar A, Hicsonmez A, Andrieu MN, Kurtman C. Mid-course thoracic radiotherapy with cisplatin-etoposide chemotherapy in limited-stage small-cell lung cancer. Medical Oncology. 2006;23(4):499-505.

17. Altinbas M, Dikilitas M, Ozkan M, Dogu GG, Er O, Coskun HS. The effect of small-molecular-weight heparin added to chemotherapy on survival in small-cell lung cancer-A retrospective analysis. Indian Journal of Cancer. 2014;51(3):324-9.

18. Aruajo AM, Mendez JC, Coelho AL, Sousa B, Barata F, Figueiredo A, et al. Phase II study of celecoxib with cisplatin plus etoposide in extensive-stage small cell lung cancer. Cancer Investigation. 2009;27(4):391-6.

19. Arinc S, Gonlugur U, Devran O, Erdal N, Ece F, Ertugrul M, et al. Prognostic factors in patients with small cell lung carcinoma. Medical oncology (Northwood, London, England). 2010;27(2):237-41.

20. Ariyoshi Y, Fukuoka M, Furuse K, Saijo N, Ikegami H, Nishiwaki Y, et al. Concurrent Cisplatin-etoposide Chemotherapy plus Thoracic Radiotherapy for Limited-stage Small Cell Lung Cancer. Japanese Journal of Clinical Oncology. 1994;24(5):275-81.

21. Artal-Cortes A, Gomez-Codina J, Gonzalez-Larriba JL, Barneto I, Carrato A, Isla D, et al. Prospective randomized phase III trial of etoposide/cisplatin versus high-dose epirubicin/cisplatin in small-cell lung cancer. Clinical lung cancer. 2004;6(3):175-83.

22. Asamoto H, Kawahara M, Iwami F, Kuba M, Furuse K, Tamura T, et al. Cisplatin plus oral etoposide in the treatment of patients with advanced small cell lung cancer. Japan Clinical Oncology Group. Japanese Journal of Clinical Oncology. 1998;28(12):745-8. 
23. Baka S, Califano R, Ferraldeschi R, Aschroft L, Thatcher N, Taylor $P$, et al. Phase III randomised trial of doxorubicin-based chemotherapy compared with platinum-based chemotherapy in small-cell lung cancer. British journal of cancer. 2008;99(3):442-7.

24. Baldotto CS, Cronemberger EH, de Biasi P, Zamboni M, Sousa A, Zukin M, et al. Palliative care in poorperformance status small cell lung cancer patients: is there a mandatory role for chemotherapy? Supportive Care in Cancer. 2012;20(11):2721-7.

25. Beith JM, Clarke SJ, Woods RL, Bell DR, Levi JA. Long-term follow-up of a randomised trial of combined chemoradiotherapy induction treatment, with and without maintenance chemotherapy in patients with small cell carcinoma of the lung. European Journal of Cancer. 1996;32A(3):438-43.

26. Bettington CS, Tripcony L, Bryant G, Hickey B, Pratt G, Fay M. A retrospective analysis of survival outcomes for two different radiotherapy fractionation schedules given in the same overall time for limited stage small cell lung cancer. Journal of Medical Imaging and Radiation Oncology. 2013;57(1):105-12.

27. Bishop JF, Raghavan D, Stuart-Harris R, Morstyn G, Aroney R, Kefford R, et al. Carboplatin (CBDCA, JM-8) and VP-16-213 in previously untreated patients with small-cell lung cancer. Journal of clinical oncology : official journal of the American Society of Clinical Oncology. 1987;5(10):1574-8.

28. Boni C, Cocconi G, Bisagni G, Ceci G, Peracchia G. Cisplatin and etoposide (VP-16) as a single regimen for small cell lung cancer. A phase II trial. Cancer. 1989;63(4):638-42.

29. Bonner JA, Sloan JA, Shanahan TG, Brooks BJ, Marks RS, Krook JE, et al. Phase III comparison of twice-daily split-course irradiation versus once-daily irradiation for patients with limited stage small-cell lung carcinoma. Journal of Clinical Oncology. 1999;17(9):2681-91.

30. Bunn PA, Jr., Crowley J, Kelly K, Hazuka MB, Beasley K, Upchurch C, et al. Chemoradiotherapy with or without granulocyte-macrophage colony-stimulating factor in the treatment of limited-stage small-cell lung cancer: a prospective phase III randomized study of the Southwest Oncology Group. Journal of clinical oncology : official journal of the American Society of Clinical Oncology. 1995;13(7):1632-41.

31. Chen GY, Jiang GL, Wang L, Qian H, Fu XL, Yang H, et al. Cisplatin/etoposide chemotherapy combined with twice daily thoracic radiotherapy for limited small-cell lung cancer: a clinical phase II trial. International journal of radiation oncology, biology, physics. 2005;61(1):70-5.

32. Chewaskulyong B, Thongprasert S. Preliminary study of efficacy of intravenous cisplatin plus oral etoposide in small cell lung cancer. Journal of the Medical Association of Thailand. 1998;81(1):37-41.

33. Cho SH, Kim HK, Jang HJ, Park MJ. Modified one-day etoposide and cisplatin combination for previously untreated extensive-disease small-cell lung cancer: A retrospective evaluation of 36 cases. Molecular and Clinical Oncology. 2015;3(4):914-8.

34. Colbeck M, Price T, Pittman K, Sukumaran S, Hooper B, Tuck M, et al. Patterns of care and survival in small cell lung cancer: A single unit experience. Asia-Pacific Journal of Clinical Oncology. 2009;5:A191-A2.

35. Cuffe S, Moua T, Summerfield R, Roberts H, Jett J, Shepherd FA. Characteristics and outcomes of small cell lung cancer patients diagnosed during two lung cancer computed tomographic screening programs in heavy smokers. Journal of Thoracic Oncology: Official Publication of the International Association for the Study of Lung Cancer. 2011;6(4):818-22.

36. De Ruysscher D, Bremer RH, Koppe F, Wanders S, van Haren E, Hochstenbag M, et al. Omission of elective node irradiation on basis of CT-scans in patients with limited disease small cell lung cancer: a phase II trial. Radiotherapy and oncology : journal of the European Society for Therapeutic Radiology and Oncology. 2006;80(3):307-12.

37. Dimitroulis J, Rapti A, Stathopoulos GP, Rigatos S, Stathopoulos J, Koutantos J, et al. Comparison of cisplatinpaclitaxel combination versus cisplatin-etoposide in patients with small-cell lung cancer: a Phase III study. Oncology Reports. 2008;20(4):879-84.

38. Eckardt JR, von Pawel J, Papai Z, Tomova A, Tzekova V, Crofts TE, et al. Open-label, multicenter, randomized, phase III study comparing oral topotecan/cisplatin versus etoposide/cisplatin as treatment for chemotherapy-naive patients with extensive-disease small-cell lung cancer. Journal of Clinical Oncology. 2006;24(13):2044-51.

39. Einhorn LH, Loehrer PJ. Hoosier Oncology Group studies in extensive and recurrent small cell lung cancer. Seminars in Oncology. 1995;22(1 SUPPL. 2):28-31.

40. Ellis PM, Delaney G, Della-Fiorentina S, Moylan E. Assessing outcomes of cancer care: Lessons to be learned from a retrospective review of the management of small cell lung cancer at the Cancer Therapy Centre, Liverpool Hospital, January 1996-July 2000. Australasian Radiology. 2004;48(3):364-70. 
41. Evans WK, Shepherd FA, Feld R, Osoba D, Dang P, Deboer G. VP-16 and cisplatin as first-line therapy for small-cell lung cancer. Journal of clinical oncology : official journal of the American Society of Clinical Oncology. 1985;3(11):1471-7.

42. Evans WK, Eisenhauer E, Hughes P, Maroun JA, Ayoub J, Shepherd FA, et al. VP-16 and carboplatin in previously untreated patients with extensive small cell lung cancer: a study of the National Cancer Institute of Canada Clinical Trials Group. British journal of cancer. 1988;58(4):464-8.

43. Evans WK, Radwi A, Tomiak E, Logan DM, Martins H, Stewart DJ, et al. Oral etoposide and carboplatin: Effective therapy for elderly patients with small cell lung cancer. American Journal of Clinical Oncology: Cancer Clinical Trials. 1995;18(2):149-55.

44. Faivre-Finn C, Snee M, Ashcroft L, Appel W, Barlesi F, Bhatnagar A, et al. Concurrent once-daily versus twicedaily chemoradiotherapy in patients with limited-stage small-cell lung cancer (CONVERT): an open-label, phase 3, randomised, superiority trial. The Lancet Oncology. 2017;18(8):1116-25.

45. Faivre-Finn C, Blackhall F, Ashcroft L, Thatcher N, Taylor P, Lorigan P. Long-term toxicity report from a Phase II study of accelerated twice-daily (BD) versus high dose once-daily (OD) thoracic radiotherapy (RT) with concurrent chemotherapy for limited-stage small cell lung cancer (LS-SCLC). International Journal of Radiation Oncology Biology Physics. 2011;1):S589.

46. Figoli F, Veronesi A, Trovo MG, Errante D, Della Valentina M, Zagonel V, et al. Combination chemotherapy with cisplatin and etoposide associated with radiotherapy in the treatment of small-cell lung cancer. Cancer Chemotherapy \& Pharmacology. 1989;24(6):381-5.

47. Fink TH, Huber RM, Heigener DF, Eschbach C, Waller C, Steinhauer EU, et al. Topotecan/cisplatin compared with cisplatin/etoposide as first-line treatment for patients with extensive disease small-cell lung cancer: final results of a randomized phase III trial. Journal of Thoracic Oncology: Official Publication of the International Association for the Study of Lung Cancer. 2012;7(9):1432-9.

48. Fukuda M, Nakamura Y, Kinoshita A, Soejima Y, Yamaguchi H, Ikeda T, et al. Phase Il study of irinotecan and cisplatin with concurrent split-course radiotherapy in limited-disease small cell lung cancer. Cancer Chemotherapy \& Pharmacology. 2012;70(5):645-51.

49. Fukuoka M, Furuse K, Saijo N, Nishiwaki Y, Ikegami H, Tamura T, et al. Randomized trial of cyclophosphamide, doxorubicin, and vincristine versus cisplatin and etoposide versus alternation of these regimens in small-cell lung cancer. Journal of the National Cancer Institute. 1991;83(12):855-61.

50. Giuliani ME, Lindsay PE, Sun A, Bezjak A, Le LW, Brade A, et al. Locoregional failures following thoracic irradiation in patients with limited-stage small cell lung carcinoma. Radiotherapy and Oncology. 2012;102(2):263-7.

51. Greco FA, Hainsworth JD. Etoposide phosphate or etoposide with cisplatin in the treatment of small cell lung cancer: randomized phase II trial. Lung Cancer. 1995;12 Suppl 3:S85-95.

52. Ha I-B, Jeong B-K, Jeong H, Choi H-S, Chai G-Y, Kang M-H, et al. Effect of early chemoradiotherapy in patients with limited stage small cell lung cancer. Radiation Oncology Journal. 2013;31(4):185-90.

53. Hainsworth JD, Levitan N, Wampler GL, Belani CP, Seyedsadr MS, Randolph J, et al. Phase II randomized study of cisplatin plus etoposide phosphate or etoposide in the treatment of small-cell lung cancer. Journal of Clinical Oncology. 1995;13(6):1436-42.

54. Han JY, Kim HT, Lim KY, Yoon SJ, Lee DH, Lee JS. Randomized phase II study of maintenance irinotecan therapy versus observation following induction chemotherapy with irinotecan and cisplatin in extensive disease small cell lung cancer. Journal of thoracic oncology : official publication of the International Association for the Study of Lung Cancer. 2008;3(9):1039-45.

55. Han D, Qin Q, Hao S, Huang W, Wei Y, Zhang Z, et al. Feasibility and efficacy of simultaneous integrated boost intensity-modulated radiation therapy in patients with limited-disease small cell lung cancer. Radiation Oncology. 2014;9:280.

56. Han JY, Cho KH, Lee DH, Kim HY, Kim EA, Lee SY, et al. Phase Il study of irinotecan plus cisplatin induction followed by concurrent twice-daily thoracic irradiation with etoposide plus cisplatin chemotherapy for limiteddisease small-cell lung cancer. Journal of Clinical Oncology. 2005;23(15):3488-94.

57. Han JY, Lee DH, Lee SY, Park CG, Kim HY, Kim EA, et al. A phase II study of dose-intensified weekly concomitant administration of cisplatin and irinotecan in chemonaive patients with extensive-disease small-cell lung cancer. Medical Oncology. 2005;22(3):281-90.

58. Han JY, Lim KY, Yu SY, Yun T, Kim HT, Lee JS. A phase 2 study of irinotecan, cisplatin, and simvastatin for untreated extensive-disease small cell lung cancer. Cancer. 2011;117(10):2178-85. 
59. Han TJ, Kim HJ, Wu HG, Heo DS, Kim YW, Lee SH. Comparison of treatment outcomes between involved-field and elective nodal irradiation in limited-stage small cell lung cancer. Japanese Journal of Clinical Oncology. 2012;42(10):948-54.

60. Hanna N, Bunn Jr PA, Langer C, Einhorn L, Guthrie Jr T, Beck T, et al. Randomized phase III trial comparing irinotecan/cisplatin with etoposide/cisplatin in patients with previously untreated extensive-stage disease small-cell lime cancer. Journal of Clinical Oncology. 2006;24(13):2038-43.

61. Hong YS, Lee HR, Park S, Lee SC, Hwang IG, Park BB, et al. Three-week schedule of irinotecan plus cisplatin in patients with previously untreated extensive-stage small-cell lung cancer. British journal of cancer. 2006;95(12):1648-52.

62. Hu X, Bao Y, Zhang L, Guo Y, Chen YY, Li KX, et al. Omitting elective nodal irradiation and irradiating postinduction versus preinduction chemotherapy tumor extent for limited-stage small cell lung cancer: interim analysis of a prospective randomized noninferiority trial. Cancer. 2012;118(1):278-87.

63. Hugli A, Moro D, Mermillod B, Bolla M, Alberto P, Bonnefoi H, et al. Phase II trial of up-front accelerated thoracic radiotherapy combined with chemotherapy and optional up-front prophylactic cranial irradiation in limited small-cell lung cancer. Groupe d'Oncologie Thoracique des Regions Alpines. Journal of Clinical Oncology.

2000;18(8):1662-7.

64. Bae SH, Ryoo HM, Do YR, Song HS, Kwon KY, Kim MK, et al. A phase Il study of biweekly irinotecan and cisplatin for patients with extensive stage disease small cell lung cancer. Lung Cancer. 2008;59(1):76-80.

65. Ikeda T, Yamaguchi H, Doi S, Nakatomi K, Nakamura Y, Nagashima S, et al. Phase II study of irinotecan and cisplatin with concurrent split-course radiotherapy in limited-disease small-cell lung cancer. Journal of Thoracic Oncology. 2011;2):S1342-S3.

66. Inal A, Kaplan MA, Kucukoner M, Urakci Z, Karakus A, Nas N, et al. Is diabetes mellitus a prognostic factor for survival in patients with small cell lung cancer? Asian Pacific Journal of Cancer Prevention: Apjcp. 2012;13(4):1491-4.

67. Jara C, Gomez-Aldaravi JL, Tirado R, Meseguer VA, Alonso C, Fernandez A. Small-cell lung cancer in the elderly--is age of patient a relevant factor? Acta Oncologica. 1999;38(6):781-6.

68. Jeong HC, Lee SY, Lee SY, Kim JH, Shin C, Shim JJ, et al. Phase II study of irinotecan plus cisplatin with concurrent radiotherapy for the patients with limited-disease small-cell lung cancer. Lung Cancer. 2006;53(3):361-6.

69. Jeremic B, Shibamoto Y, Acimovic L, Milisavljevic S. Initial versus delayed accelerated hyperfractionated radiation therapy and concurrent chemotherapy in limited small-cell lung cancer: a randomized study. Journal of clinical oncology : official journal of the American Society of Clinical Oncology. 1997;15(3):893-900.

70. Jeremic B, Shibamoto Y, Acimovic L, Milisavljevic S. Carboplatin, etoposide, and accelerated hyperfractionated radiotherapy for elderly patients with limited small cell lung carcinoma: a phase II study. Cancer. 1998;82(5):836-41.

71. Jezdic S, Jelic S, Radosavljevic D, Kezic I, Nikolic-Tomasevic Z, Popov I. P-773 Cisplatin or carboplatin-based regimens for small-cell lungcancer \&\#x2014; A randomized phase III study. Lung Cancer.49:S322.

72. Johnson DH, Ruckdeschel JC, Keller JH, Lyman GH, Kallas GJ, Macdonald J, et al. A randomized trial to compare intravenous and oral etoposide in combination with cisplatin for the treatment of small cell lung cancer. Cancer. 1991;67(1 Suppl):245-9.

73. Johnson DH, Turrisi AT, Chang AY, Blum R, Bonomi P, Ettinger D, et al. Alternating chemotherapy and twicedaily thoracic radiotherapy in limited-stage small-cell lung cancer: a pilot study of the Eastern Cooperative Oncology Group. Journal of Clinical Oncology. 1993;11(5):879-84.

74. Kaasa S. Associations between comorbidity, treatment toxicity and overall survival in limited disease smallcell lung cancer. . 2015.

75. Kang MH, Go SI, Song HN, Lee A, Kim SH, Kang JH, et al. The prognostic impact of the neutrophil-tolymphocyte ratio in patients with small-cell lung cancer. British journal of cancer. 2014;111(3):452-60.

76. Karam I, Jiang SY, Khaira M, Lee CW, Schellenberg D. Outcomes of small cell lung cancer patients treated with cisplatin-etoposide versus carboplatin-etoposide. American journal of clinical oncology. 2015;38(1):51-4.

77. Lee JE, Park HS, Jung SS, Kim JO, Kim SY. Phase II study of a 3-week schedule of irinotecan combined with cisplatin in previously untreated extensive-stage small-cell lung cancer. Oncology. 2007;73(1-2):76-80.

78. Kelley MJ, Bogart JA, Hodgson LD, Ansari RH, Atkins JN, Pang H, et al. Phase Il study of induction cisplatin and irinotecan followed by concurrent carboplatin, etoposide, and thoracic radiotherapy for limited-stage small-cell lung cancer, CALGB 30206. Journal of Thoracic Oncology: Official Publication of the International Association for the Study of Lung Cancer. 2013;8(1):102-8. 
79. Kim HG, Lee GW, Kang JH, Kang MH, Hwang IG, Kim SH, et al. Combination chemotherapy with irinotecan and cisplatin in elderly patients ( $>65$ years) with extensive-disease small-cell lung cancer. Lung Cancer. 2008;61(2):220-6.

80. Komaki R, Paulus R, Ettinger DS, Videtic GM, Bradley JD, Glisson BS, et al. Phase II study of accelerated highdose radiotherapy with concurrent chemotherapy for patients with limited small-cell lung cancer: Radiation Therapy Oncology Group protocol 0239. International journal of radiation oncology, biology, physics. 2012;83(4):e531-6.

81. Kubota K, Nishiwaki Y, Sugiura T, Noda K, Mori K, Kawahara M, et al. Pilot Study of Concurrent Etoposide and Cisplatin Plus Accelerated Hyperfractionated Thoracic Radiotherapy Followed by Irinotecan and Cisplatin for LimitedStage Small Cell Lung Cancer: Japan Clinical Oncology Group 9903. Clinical Cancer Research. 2005;11(15):5534-8.

82. Kubota K, Hida T, Ishikura S, Mizusawa J, Nishio M, Kawahara M, et al. Etoposide and cisplatin versus irinotecan and cisplatin in patients with limited-stage small-cell lung cancer treated with etoposide and cisplatin plus concurrent accelerated hyperfractionated thoracic radiotherapy (JCOG0202): a randomised phase 3 study. Lancet Oncology. 2014;15(1):106-13.

83. Kudoh S, Fujiwara Y, Takada Y, Yamamoto H, Kinoshita A, Ariyoshi Y, et al. Phase Il study of irinotecan combined with cisplatin in patients with previously untreated small-cell lung cancer. West Japan Lung Cancer Group. Journal of Clinical Oncology. 1998;16(3):1068-74.

84. Langer CJ, Albert I, Ross HJ, Kovacs P, Blakely L, Pajkos G, et al. Randomized phase II study of carboplatin and etoposide with or without obatoclax mesylate in extensive-stage small cell lung cancer. Lung Cancer. 2014;85(3):420-8.

85. Lara PN, Jr., Natale R, Crowley J, Lenz HJ, Redman MW, Carleton JE, et al. Phase III trial of irinotecan/cisplatin compared with etoposide/cisplatin in extensive-stage small-cell lung cancer: clinical and pharmacogenomic results from SWOG S0124. Journal of Clinical Oncology. 2009;27(15):2530-5.

86. Larive $S$, Bombaron $P$, Riou R, Fournel P, Perol M, Lena $\mathrm{H}$, et al. Carboplatin-etoposide combination in small cell lung cancer patients older than 70 years: a phase II trial. Lung Cancer. 2002;35(1):1-7.

87. Caprario LC, Kent DM, Strauss GM. Effects of chemotherapy on survival of elderly patients with small-cell lung cancer: analysis of the SEER-medicare database. Journal of Thoracic Oncology: Official Publication of the International Association for the Study of Lung Cancer. 2013;8(10):1272-81.

88. Law AB, Erridge SC, MacKean MJ, Kerr GR, Ironside JA, Little FA, et al. Improving outcomes for limited stage small cell lung cancer patients in Scotland with concomitant chemoradiation. Clinical Oncology (Royal College of Radiologists). 2007;19(3):188-93.

89. Lee YJ, Cho A, Cho BC, Yun M, Kim SK, Chang J, et al. High Tumor Metabolic Activity as Measured by Fluorodeoxyglucose Positron Emission Tomography Is Associated with Poor Prognosis in Limited and Extensive Stage Small-Cell Lung Cancer. Clinical Cancer Research. 2009;15(7):2426-32.

90. Jeong EL, Hee SP, Sung SJ, Ju OK, Moon JC, Jin HK, et al. Phase II study of induction irinotecan + cisplatin chemotherapy followed by concurrent irinotecan + cisplatin plus twice-daily thoracic radiotherapy. Tuberculosis and Respiratory Diseases. 2007;63(2):154-64.

91. Lee J, Choi J, Kim JW, Cho J, Lee CG. Early treatment volume reduction rate as a prognostic factor in patients treated with chemoradiotherapy for limited stage small cell lung cancer. Radiation Oncology Journal.

2015;33(2):117-25.

92. Lee J, Kim JO, Jung CK, Kim YS, Yoo le R, Choi WH, et al. Metabolic activity on [18f]-fluorodeoxyglucosepositron emission tomography/computed tomography and glucose transporter-1 expression might predict clinical outcomes in patients with limited disease small-cell lung cancer who receive concurrent chemoradiation. Clinical lung cancer. 2014;15(2):e13-21.

93. Lee SH, Ahn YC, Kim HJ, Lim DH, Lee SI, Nam E, et al. Early concurrent chemoradiotherapy with prolonged oral etoposide and cisplatin for limited-stage small-cell lung cancer. Japanese Journal of Clinical Oncology. 2003;33(12):620-5.

94. Lee SM, Woll PJ, Rudd R, Ferry D, O'Brien M, Middleton G, et al. Anti-angiogenic therapy using thalidomide combined with chemotherapy in small cell lung cancer: a randomized, double-blind, placebo-controlled trial. Journal of the National Cancer Institute. 2009;101(15):1049-57.

95. Li C, Xiong $\mathrm{Y}$, Zhou Z, Peng $\mathrm{Y}$, Huang $\mathrm{H}, \mathrm{Xu} \mathrm{M}$, et al. Stereotactic body radiotherapy with concurrent chemotherapy extends survival of patients with limited stage small cell lung cancer: a single-center prospective phase II study. Medical Oncology. 2014;31(12):369.

96. Liu S, Guo H, Kong L, Li H, Zhang Y, Zhu H, et al. The prognostic factors in the elderly patients with small cell lung cancer: a retrospective analysis from a single cancer institute. International Journal of Clinical and Experimental Pathology. 2015;8(9):11033-41. 
97. Liu W, Zhang CC, Li K. Prognostic value of chemotherapy-induced leukopenia in small-cell lung cancer. Cancer Biology and Medicine. 2013;10(2):92-8.

98. Loehrer PJ, Sr., Ansari R, Gonin R, Monaco F, Fisher W, Sandler A, et al. Cisplatin plus etoposide with and without ifosfamide in extensive small-cell lung cancer: a Hoosier Oncology Group study. Journal of clinical oncology : official journal of the American Society of Clinical Oncology. 1995;13(10):2594-9.

99. Luikart SD, Goutsou M, Mitchell ED, Van Echo DA, Modeas CR, Propert KJ, et al. Phase I/II trial of etoposide and carboplatin in extensive small-cell lung cancer. A report from the Cancer and Leukemia Group B. American journal of clinical oncology. 1993;16(2):127-31.

100. Matsui K, Masuda N, Fukuoka M, Yana T, Hirashima T, Komiya T, et al. Phase II trial of carboplatin plus oval etoposide for elderly patients with small-cell lung cancer. British journal of cancer. 1998;77(11):1961-5.

101. Mavroudis D, Papadakis E, Veslemes M, Tsiafaki X, Stavrakakis J, Kouroussis C, et al. A multicenter randomized clinical trial comparing paclitaxel-cisplatin-etoposide versus cisplatin-etoposide as first-line treatment in patients with small-cell lung cancer. Annals of oncology : official journal of the European Society for Medical Oncology. 2001;12(4):463-70.

102. McClay EF, Bogart J, Herndon JE, 2nd, Watson D, Evans L, Seagren SL, et al. A phase III trial evaluating the combination of cisplatin, etoposide, and radiation therapy with or without tamoxifen in patients with limited-stage small cell lung cancer: Cancer and Leukemia Group B Study (9235). American journal of clinical oncology.

2005;28(1):81-90.

103. Miller AA, Herndon JE, 2nd, Hollis DR, Ellerton J, Langleben A, Richards F, 2nd, et al. Schedule dependency of 21-day oral versus 3-day intravenous etoposide in combination with intravenous cisplatin in extensive-stage smallcell lung cancer: a randomized phase III study of the Cancer and Leukemia Group B. Journal of Clinical Oncology. 1995;13(8):1871-9.

104. Minami H, Saka H, Sakai S, Yamamoto M, Shimokata K. A phase II study of carboplatin and prolonged administration of oral etoposide in patients with small-cell lung cancer. Acta Oncologica. 1997;36(7):765-9. 105. Minegishi Y, Kuribayashi H, Kitamura K, Mizutani H, Kosaihira S, Okano T, et al. The feasibility study of Carboplatin plus Etoposide for advanced small cell lung cancer with idiopathic interstitial pneumonias. Journal of Thoracic Oncology: Official Publication of the International Association for the Study of Lung Cancer. 2011;6(4):8017.

106. Mitchell EP, Perry MC, Luikart SD, Cirrincione CT, Van Echo DA, Herndon JE, 2nd, et al. A phase I/II trial of etoposide and cisplatin in extensive small cell lung cancer: a cancer and leukemia group B study. Lung Cancer. 1996;15(2):215-23.

107. Miyamoto H, Nakabayashi T, Isobe H, Akita H, Kawakami Y, Arimoto T, et al. A phase III comparison of etoposide/cisplatin with or without added ifosfamide in small-cell lung cancer. Oncology. 1992;49(6):431-5.

108. Mori K, Ohta S, Kishiro I, Yokoyama K, Suga Y, Tominaga K. Phase II study of infusional cisplatin in combination with etoposide in the treatment of small cell lung cancer. European Journal of Cancer. 1995;31A(11):1781-4.

109. Murphy PB, Hainsworth JD, Greco FA, Hande KR, DeVore RF, Johnson DH. A phase II trial of cisplatin and prolonged administration of oral etoposide in extensive-stage small cell lung cancer. Cancer. 1992;69(2):370-5.

110. S Naidu PRW, T Parent, M E Picton. Limited-stage small cell lung cancer treated with cisplatin/irinotecan and concurrent thoracic radiation therapy. 2014 ASCO meeting. 2014.

111. Niell HB, Herndon JE, 2nd, Miller AA, Watson DM, Sandler AB, Kelly K, et al. Randomized phase III intergroup trial of etoposide and cisplatin with or without paclitaxel and granulocyte colony-stimulating factor in patients with extensive-stage small-cell lung cancer: Cancer and Leukemia Group B Trial 9732. Journal of Clinical Oncology. 2005;23(16):3752-9.

112. Noda K, Nishiwaki Y, Kawahara M, Negoro S, Sugiura T, Yokoyama A, et al. Irinotecan plus Cisplatin Compared with Etoposide plus Cisplatin for Extensive Small-Cell Lung Cancer. New England Journal of Medicine. 2002;346(2):85-91.

113. Okamoto H, Watanabe K, Nishiwaki Y, Mori K, Kurita Y, Hayashi I, et al. Phase II study of area under the plasma-concentration-versus-time curve-based carboplatin plus standard-dose intravenous etoposide in elderly patients with small-cell lung cancer. Journal of Clinical Oncology. 1999;17(11):3540-5.

114. Okamoto K, Okamoto I, Takezawa K, Tachibana I, Fukuoka M, Nishimura Y, et al. Cisplatin and etoposide chemotherapy combined with early concurrent twice-daily thoracic radiotherapy for limited-disease small cell lung cancer in elderly patients. Japanese Journal of Clinical Oncology. 2010;40(1):54-9. 
115. Marcos Oset M, Martinez Lopez E, Arias De La Vega F, Arraras Urdaniz JI, Calasanz Abinzano MJ, Dominguez Dominguez MA. Chemotherapy and concurrent hyperfractionated radiotherapy for patients with limited small-cell lung cancer: Long term results from a single institution and a review of the literature. Oncologia. 2003;26(9):27-36. 116. Pereira AAR, Assis RJF, Pereira EdC, Lima VC, Nugue PB, Pereira JR. Cisplatin, gemcitabine, and vinorelbine (PGV) compared with cisplatin and etoposide (PE) in the first-line treatment of extensive-stage small-cell lung cancer: Two Brazilian institution experience. J Clin Oncol 31, 2013 (suppl; abstr e18548). 2013.

117. Pfeiffer $P$, Sorensen $P$, Rose $C$. Is carboplatin and oral etoposide an effective and feasible regimen in patients with small cell lung cancer? European Journal of Cancer Part A: General Topics. 1995;31(1):64-9.

118. Pujol JL, Daures JP, Riviere A, Quoix E, Westeel V, Quantin X, et al. Etoposide plus cisplatin with or without the combination of 4'-epidoxorubicin plus cyclophosphamide in treatment of extensive small-cell lung cancer: a French Federation of Cancer Institutes multicenter phase III randomized study. Journal of the National Cancer Institute. 2001;93(4):300-8.

119. Quoix E, Breton JL, Daniel C, Jacoulet P, Debieuvre D, Paillot N, et al. Etoposide phosphate with carboplatin in the treatment of elderly patients with small-cell lung cancer: a phase II study. Annals of Oncology. 2001;12(7):957-

62.

120. Quoix E, Breton JL, Gervais R, Wilson J, Schramel F, Cardenal F, et al. A randomised phase II study of the efficacy and safety of intravenous topotecan in combination with either cisplatin or etoposide in patients with untreated extensive disease small-cell lung cancer. Lung Cancer. 2005;49(2):253-61.

121. Reymen B, Van Loon J, van Baardwijk A, Wanders R, Borger J, Dingemans AM, et al. Total gross tumor volume is an independent prognostic factor in patients treated with selective nodal irradiation for stage I to III small cell lung cancer. International journal of radiation oncology, biology, physics. 2013;85(5):1319-24.

122. Roth BJ, Johnson DH, Einhorn LH, Schacter LP, Cherng NC, Cohen HJ, et al. Randomized study of cyclophosphamide, doxorubicin, and vincristine versus etoposide and cisplatin versus alternation of these two regimens in extensive small-cell lung cancer: a phase III trial of the Southeastern Cancer Study Group. Journal of clinical oncology : official journal of the American Society of Clinical Oncology. 1992;10(2):282-91.

123. Rowland KM, Jr., Loprinzi CL, Shaw EG, Maksymiuk AW, Kuross SA, Jung SH, et al. Randomized double-blind placebo-controlled trial of cisplatin and etoposide plus megestrol acetate/placebo in extensive-stage small-cell lung cancer: a North Central Cancer Treatment Group study. Journal of Clinical Oncology. 1996;14(1):135-41.

124. Rudin CM, Salgia R, Wang X, Hodgson LD, Masters GA, Green M, et al. Randomized Phase II Study of Carboplatin and Etoposide With or Without the bcl-2 Antisense Oligonucleotide Oblimersen for Extensive-Stage Small-Cell Lung Cancer: CALGB 30103. Journal of clinical oncology : official journal of the American Society of Clinical Oncology. 2008;26(6):870-6.

125. Ruiz-Valdepeñas A, Palka M, Ibeas P, Doger de Speville BG, Almagro E, Callejo DP, et al. Hybrid scheme with carboplatin and etoposide intravenous (iv) and oral in patients with small cell lung cancer: Should we treat in a different way based on the age-. J Clin Oncol 30, 2012 (suppl; abstr e17515). 2012.

126. Samantas E, Skarlos DV, Pectasides D, Nicolaides P, Kalofonos H, Mylonakis N, et al. Combination chemotherapy with low doses of weekly Carboplatin and oral Etoposide in poor risk small cell lung cancer. Lung Cancer. 1999;23(2):159-68.

127. Schild SE, Bonner JA, Hillman S, Kozelsky TF, Vigliotti AP, Marks RS, et al. Results of a phase II study of highdose thoracic radiation therapy with concurrent cisplatin and etoposide in limited-stage small-cell lung cancer (NCCTG 95-20-53). Journal of Clinical Oncology. 2007;25(21):3124-9.

128. Schild SE, Stella PJ, Brooks BJ, Mandrekar S, Bonner JA, McGinnis WL, et al. Results of combined-modality therapy for limited-stage small cell lung carcinoma in the elderly. Cancer. 2005;103(11):2349-54.

129. Schiller JH, Adak S, Cella D, DeVore RF, 3rd, Johnson DH. Topotecan versus observation after cisplatin plus etoposide in extensive-stage small-cell lung cancer: E7593--a phase III trial of the Eastern Cooperative Oncology Group. Journal of clinical oncology : official journal of the American Society of Clinical Oncology. 2001;19(8):2114-22. 130. Schiller JH, Ettinger DS, Larson MM, Gradishar W, Merkel D, Johnson DH. Phase II trial of oral etoposide plus cisplatin in extensive stage small cell carcinoma of the lung: an Eastern Cooperative Oncology Group study. European Journal of Cancer. 1994;30A(2):158-61.

131. Schmittel A, Sebastian M, Fischer von Weikersthal L, Martus P, Gauler TC, Kaufmann C, et al. A German multicenter, randomized phase III trial comparing irinotecan-carboplatin with etoposide-carboplatin as first-line therapy for extensive-disease small-cell lung cancer. Annals of Oncology. 2011;22(8):1798-804.

132. Sculier JP, Lafitte JJ, Efremidis A, Florin MC, Lecomte J, Berchier MC, et al. A phase III randomised study of concomitant induction radiochemotherapy testing two modalities of radiosensitisation by cisplatin (standard versus daily) for limited small-cell lung cancer. Annals of Oncology. 2008;19(10):1691-7. 
133. Segawa Y, Ueoka H, Kiura K, Tabata M, Takigawa N, Hiraki Y, et al. Phase I/Il study of altered schedule of cisplatin and etoposide administration and concurrent accelerated hyperfractionated thoracic radiotherapy for limited-stage small-cell lung cancer. Lung Cancer. 2003;41(1):13-20.

134. Seifart U, Jensen K, Ukena J, Mueller C, Schroder M, Fuhr HG, et al. Randomized phase II study comparing topotecan/cisplatin administration for 5 days versus 3 days in the treatment of extensive stage small cell lung cancer (SCLC). Lung Cancer. 2005;48(3):415-22.

135. Sekine I, Nokihara H, Takeda K, Nishiwaki Y, Nakagawa K, Isobe H, et al. Randomised phase II trial of irinotecan plus cisplatin vs irinotecan, cisplatin plus etoposide repeated every 3 weeks in patients with extensivedisease small-cell lung cancer. British journal of cancer. 2008;98(4):693-6.

136. Sekine I, Okamoto H, Horai T, Nakagawa K, Ohmatsu H, Yokoyama A, et al. A randomized phase III study of single-agent amrubicin vs. carboplatin/etoposide in elderly patients with extensive-disease small-cell lung cancer. Clinical lung cancer. 2014;15(2):96-102.

137. Shi Y, Hu Y, Hu X, Li X, Lin L, Han X. Cisplatin combined with irinotecan or etoposide for untreated extensivestage small cell lung cancer: A multicenter randomized controlled clinical trial. Thoracic Cancer. 2015;6(6):785-91.

138. Shimizu T, Sekine I, Sumi M, Ito Y, Yamada K, Nokihara H, et al. Concurrent chemoradiotherapy for limiteddisease small cell lung cancer in elderly patients aged 75 years or older. Japanese Journal of Clinical Oncology. 2007;37(3):181-5.

139. Shukuya T, Takahashi T, Harada H, Ono A, Akamatsu H, Taira T, et al. Chemoradiotherapy for limited-disease small-cell lung cancer in elderly patients aged 75 years or older. Japanese Journal of Clinical Oncology.

2013;43(2):176-83.

140. Skarlos DV, Samantas E, Briassoulis E, Panoussaki E, Pavlidis N, Kalofonos HP, et al. Randomized comparison of early versus late hyperfractionated thoracic irradiation concurrently with chemotherapy in limited disease smallcell lung cancer: a randomized phase II study of the Hellenic Cooperative Oncology Group (HeCOG). Annals of Oncology. 2001;12(9):1231-8.

141. Skarlos DV, Samantas E, Kosmidis P, Fountzilas G, Angelidou M, Palamidas P, et al. Randomized comparison of etoposide-cisplatin vs. etoposide-carboplatin and irradiation in small-cell lung cancer. A Hellenic Co-operative Oncology Group study. Annals of Oncology. 1994;5(7):601-7.

142. Smith IE, Evans BD, Gore ME, Vincent MD, Repetto L, Yarnold JR, et al. Carboplatin (Paraplatin; JM8) and etoposide (VP-16) as first-line combination therapy for small-cell lung cancer. Journal of Clinical Oncology. 1987;5(2):185-9.

143. Socinski MA, Smit EF, Lorigan P, Konduri K, Reck M, Szczesna A, et al. Phase III study of pemetrexed plus carboplatin compared with etoposide plus carboplatin in chemotherapy-naive patients with extensive-stage smallcell lung cancer. Journal of Clinical Oncology. 2009;27(28):4787-92.

144. Sohn JH, Moon YW, Lee CG, Kim GE, Chung KY, Chang J, et al. Phase II trial of irinotecan and cisplatin with early concurrent radiotherapy in limited-disease small-cell lung cancer. Cancer. 2007;109(9):1845-950.

145. Sorensen M, Lassen U, Jensen PB, Osterlind K, Jeppesen N, Jensen BB, et al. Phase II study of a 3-day schedule with topotecan and cisplatin in patients with previously untreated small cell lung cancer and extensive disease. Journal of Thoracic Oncology: Official Publication of the International Association for the Study of Lung Cancer. 2008;3(8):902-6.

146. Y Sun YC, X Hao, J Wang, C Hu, B Han, X Liu, L Zhang, H Wan, Z Xia, Y Liu, W Li, M Hou, H Zhang, Q Xiu, Y Zhu, J Feng, S Qin Results of a phase III trial of amrubicin/ciapltin versus eteoposide/cisplatin as first line treatment for extensive small cell lung cancer. . ASCO meeting.

147. Sun JM, Ahn YC, Choi EK, Ahn MJ, Ahn JS, Lee SH, et al. Phase III trial of concurrent thoracic radiotherapy with either first- or third-cycle chemotherapy for limited-disease small-cell lung cancer.[Erratum appears in Ann Oncol. 2014 Aug;25(8):1672]. Annals of Oncology. 2013;24(8):2088-92.

148. Sun Y, Cheng Y, Hao X, Wang J, Hu C, Han B, et al. Randomized phase III trial of amrubicin/cisplatin versus etoposide/cisplatin as first-line treatment for extensive small-cell lung cancer. BMC Cancer. 2016;16 (1) (no pagination)(265).

149. Sundstrom S, Bremnes RM, Kaasa S, Aasebo U, Hatlevoll R, Dahle R, et al. Cisplatin and etoposide regimen is superior to cyclophosphamide, epirubicin, and vincristine regimen in small-cell lung cancer: results from a randomized phase III trial with 5 years' follow-up. Journal of Clinical Oncology. 2002;20(24):4665-72.

150. Takada M, Fukuoka M, Kawahara M, Sugiura T, Yokoyama A, Yokota S, et al. Phase III study of concurrent versus sequential thoracic radiotherapy in combination with cisplatin and etoposide for limited-stage small-cell lung cancer: results of the Japan Clinical Oncology Group Study 9104. Journal of Clinical Oncology. 2002;20(14):3054-60. 
151. Takigawa N, Fujiwara K, Ueoka H, Kiura K, Tabata M, Hiraki A, et al. Fractionated administration of irinotecan and cisplatin for treatment of extensive-disease small-cell lung cancer: a phase II study. Anticancer Research. 2003;23(1B):557-60.

152. Terashima T, Morizane C, Hiraoka N, Tsuda H, Tamura T, Shimada Y, et al. Comparison of chemotherapeutic treatment outcomes of advanced extrapulmonary neuroendocrine carcinomas and advanced small-cell lung carcinoma. Neuroendocrinology. 2012;96(4):324-32.

153. Thammakumpee K, Juthong S, Viriyachaiyo V, Rittirak W, Tanomkiat W. Clinical manifestation and survival of patients with small-cell lung cancer. Journal of the Medical Association of Thailand. 2007;90(7):1303-8.

154. Tiseo M, Boni L, Ambrosio F, Camerini A, Vitale MG, Baldini E, et al. Italian multicenter phase III randomized study of cisplatin-etoposide with or without bevacizumab as first-line treatment in extensive stage small cell lung cancer: Treatment rationale and protocol design of the GOIRC-AIFA FARM6PMFJM trial. Clinical lung cancer. 2015;16(1):67-70.

155. Turrisi AT, 3rd, Glover DJ, Mason BA. A preliminary report: concurrent twice-daily radiotherapy plus platinum-etoposide chemotherapy for limited small cell lung cancer. International journal of radiation oncology, biology, physics. 1988;15(1):183-7.

156. Turrisi AT, 3rd, Kim K, Blum R, Sause WT, Livingston RB, Komaki R, et al. Twice-daily compared with oncedaily thoracic radiotherapy in limited small-cell lung cancer treated concurrently with cisplatin and etoposide. New England Journal of Medicine. 1999;340(4):265-71.

157. Ueda H, Kuwahara M, Sakada T, Motohiro A. Chemotherapy for small cell lung cancer in patients over 80 years old. Anticancer Research. 2002;22(6B):3629-31.

158. Valladares T, Crespo PC, Caamano AG, Quintela ML. Hiperfracctioned radiochemotherapy in small cell lung cancer, a monoinstutional experience Begona. Journal of Thoracic Oncology. 2015;2):S743.

159. van Loon J, De Ruysscher D, Wanders R, Boersma L, Simons J, Oellers M, et al. Selective nodal irradiation on basis of (18)FDG-PET scans in limited-disease small-cell lung cancer: a prospective study. International journal of radiation oncology, biology, physics. 2010;77(2):329-36.

160. Veslemes M, Polyzos A, Latsi P, Dimitroulis J, Stamatiadis D, Dardoufas C, et al. Optimal duration of chemotherapy in small cell lung cancer: a randomized study of 4 versus 6 cycles of cisplatin-etoposide. Journal of Chemotherapy. 1998;10(2):136-40.

161. Viren M, Liippo K, Ojala A, Helle L, Hinkka S, Huovinen R, et al. Carboplatin and etoposide in extensive small cell lung cancer. Acta Oncologica. 1994;33(8):921-4.

162. Walewski J, Romejko-Jarosinska J, Zwolinski J, Falkowski S, Siedlecki P. Tolerability and efficacy of GM-CSF [Leucomax] in patients with small cell lung cancer treated with intensive chemotherapy. Medical Oncology. 1996;13(4):199-205.

163. Wang ZB, Ning FL, Wang XL, Cheng YF, Dong XJ, Liu CM, et al. Radiation dose is associated with prognosis of small cell lung cancer with superior vena cava syndrome. International Journal of Clinical and Experimental Medicine. 2015;8(3):4263-8.

164. Watkins JM, Fortney JA, Wahlquist AE, Shirai K, Garrett-Mayer E, Aguero EG, et al. Once-daily radiotherapy to $>$ or $=59.4 \mathrm{~Gy}$ versus twice-daily radiotherapy to $>$ or $=45.0 \mathrm{~Gy}$ with concurrent chemotherapy for limited-stage small-cell lung cancer: a comparative analysis of toxicities and outcomes. Japanese journal of radiology.

2010;28(5):340-8.

165. Watkins JM, Wahlquist AE, Zauls AJ, Shirai K, Garrett-Mayer E, Aguero EG, et al. Involved-field radiotherapy with concurrent chemotherapy for limited-stage small-cell lung cancer: disease control, patterns of failure and survival. Journal of Medical Imaging \& Radiation Oncology. 2010;54(5):483-9.

166. Wilke H, Achterrath W, Schmoll HJ, Gunzer U, Preusser P, Lenaz L. Etoposide and split-dose cisplatin in smallcell lung cancer. American journal of clinical oncology. 1988;11(5):572-8.

167. Wolf M, Havemann K, Holle R, Gropp C, Drings P, Hans K, et al. Cisplatin/etoposide versus ifosfamide/etoposide combination chemotherapy in small-cell lung cancer: a multicenter German randomized trial. Journal of Clinical Oncology. 1987;5(12):1880-9.

168. Xia B, Hong LZ, Cai XW, Zhu ZF, Liu Q, Zhao KL, et al. Phase 2 study of accelerated hypofractionated thoracic radiation therapy and concurrent chemotherapy in patients with limited-stage small-cell lung cancer. International journal of radiation oncology, biology, physics. 2015;91(3):517-23.

169. Xiao XG, Wang S, Xia S, Zou M, Li Y, Wei Y, et al. Retrospective study of irinotecan/cisplatin followed by etoposide/cisplatin or the reverse sequence in extensive-stage small cell lung cancer. OncoTargets and Therapy. 2015;8:2209-14. 
170. Yilmaz U, Anar C, Korkmaz E, Yapicioglu S, Karadogan I, Ozkok S. Carboplatin and etoposide followed by once-daily thoracic radiotherapy in limited disease small-cell lung cancer: Unsatisfactory results. Tumori.

2010;96(2):234-40.

171. Yoshida T, Yoh K, Goto K, Niho S, Umemura S, Ohmatsu H, et al. Safety and efficacy of platinum agents plus etoposide for patients with small cell lung cancer with interstitial lung disease. Anticancer Research.

2013;33(3):1175-9.

172. Zatloukal P, Cardenal F, Szczesna A, Gorbunova V, Moiseyenko V, Zhang X, et al. A multicenter international randomized phase III study comparing cisplatin in combination with irinotecan or etoposide in previously untreated small-cell lung cancer patients with extensive disease. Annals of Oncology. 2010;21(9):1810-6.

173. Zhang J, Qi HW, Zheng H, Chen M, Zhu J, Xie HK, et al. Etoposide-cisplatin alternating with vinorelbinecisplatin versus etoposide-cisplatin alone in patients with extensive disease combined with small cell lung cancer. Asian Pacific Journal of Cancer Prevention: Apjcp. 2014;15(10):4159-63.

174. Zhu H, Zhou Z, Wang Y, Bi N, Feng Q, Li J, et al. Thoracic radiation therapy improves the overall survival of patients with extensive-stage small cell lung cancer with distant metastasis. Cancer. 2011;117(23):5423-31.

175. Lima JP, dos Santos LV, Sasse EC, Lima CS, Sasse AD. Camptothecins compared with etoposide in combination with platinum analog in extensive stage small cell lung cancer: systematic review with meta-analysis. Journal of thoracic oncology : official publication of the International Association for the Study of Lung Cancer. 2010;5(12):1986-93.

176. Pujol JL, Carestia L, Daures JP. Is there a case for cisplatin in the treatment of small-cell lung cancer? A metaanalysis of randomized trials of a cisplatin-containing regimen versus a regimen without this alkylating agent. British journal of cancer. 2000;83(1):8-15.

177. Amarasena IU, Chatterjee S, Walters JA, Wood-Baker R, Fong KM. Platinum versus non-platinum chemotherapy regimens for small cell lung cancer. The Cochrane database of systematic reviews. 2015(8):Cd006849. 178. Ochi N, Hotta K, Takigawa N, Oze I, Fujiwara Y, Ichihara E, et al. Treatment-related death in patients with small-cell lung cancer in phase III trials over the last two decades. PLoS One. 2012;7(8):e42798.

179. A R, M DM, P C, RM R, H O, DV S, et al. Carboplatin- or cisplatin-based chemotherapy in first-line treatment of small-cell lung cancer: the COCIS meta-analysis of individual patient data. Journal of clinical oncology2012. p. 1692-8.

180. Lara P, Chansky K, Shibata T, Fukuda H, Tamura T, Saijo N, et al. Cisplatin + irinotecan versus cisplatin + etoposide in extensive stage small cell lung cancer (E-SCLC): Final "common arm": Comparative outcomes analysis of JCOG 9511 and SWOG 0124. Journal of Clinical Oncology. 2009;1):8027.

181. Mathijssen RH, van Alphen RJ, Verweij J, Loos WJ, Nooter K, Stoter G, et al. Clinical pharmacokinetics and metabolism of irinotecan (CPT-11). Clinical cancer research : an official journal of the American Association for Cancer Research. 2001;7(8):2182-94.

182. O'Dwyer PJ CR. Uridine diphosphate glucuronosyltransferase (UGT) $1 \mathrm{~A} 1$ and irinotecan: practical pharmacogenomics arrives in cancer therapy. Journal of Clinical Oncology. 2006;24(8):4534-8.

183. Cheng TY CS, Baade PD, Youlden DR, Nwogu C, Reid ME. The International Epidemiology of Lung Cancer: Latest Trends, Disparities, and Tumor Characteristics. J Thorac Oncol.2016. p. 1653-71.

184. Liu X JT, Li W, Li X, Zhao C, Shi J, Zhao S, Jia Y, Qiao M, Zhang L, Luo J, Gao G, Zhou F, Wu F, Chen X, He Y, Ren $\mathrm{S}$, Su C, Zhou C. Characterization of never-smoking and its association with clinical outcomes in Chinese patients with small-cell lung cancer. Lung Cancer2018. p. 109-15.

185. Sun JM CY, Ji JH, Ahn JS, Kim KM, Han J, Ahn MJ, Park K. Small-cell lung cancer detection in never-smokers: clinical characteristics and multigene mutation profiling using targeted next-generation sequencing. Annals of Oncology2015. p. 161-6.

186. Zhou F, Zhou C. Lung cancer in never smokers-the East Asian experience. Translational lung cancer research. 2018;7(4):450-63.

187. MB S, A N, P W, KR S, ZJ T, AA C. Temporal trends from 1986 to 2008 in overall survival of small cell lung cancer patients. Lung Cancer2014. p. 14-21.

188. Ducel G, Fabry, J, Nicolle, L \& World Health Organization. Dept. of Epidemic and Pandemic Alert and Response. Prevention of hospital-acquired infections : a practical guide. 2002.

189. Fried DB, Morris DE, Poole C, Rosenman JG, Halle JS, Detterbeck FC, et al. Systematic Review Evaluating the Timing of Thoracic Radiation Therapy in Combined Modality Therapy for Limited-Stage Small-Cell Lung Cancer. Journal of Clinical Oncology. 2004;22(23):4837-45. 
190. De Ruysscher D, on behalf of the RTTSCG, Lueza B, on behalf of the RTTSCG, Le Péchoux C, on behalf of the RTTSCG, et al. Impact of thoracic radiotherapy timing in limited-stage small-cell lung cancer: usefulness of the individual patient data meta-analysist. Annals of Oncology. 2016;27(10):1818-28.

191. De Ruysscher D, Pijls-Johannesma M, Bentzen SM, Minken A, Wanders R, Lutgens L, et al. Time between the first day of chemotherapy and the last day of chest radiation is the most important predictor of survival in limiteddisease small-cell lung cancer. Journal of clinical oncology : official journal of the American Society of Clinical Oncology. 2006;24(7):1057-63.

192. Aupérin A, Arriagada R, Pignon J-P, Le Péchoux C, Gregor A, Stephens RJ, et al. Prophylactic Cranial Irradiation for Patients with Small-Cell Lung Cancer in Complete Remission. New England Journal of Medicine. 1999;341(7):476-84.

193. T T, T Y, T S, H H, H N, H S, et al. Prophylactic cranial irradiation versus observation in patients with extensivedisease small-cell lung cancer: a multicentre, randomised, open-label, phase 3 trial. The Lancet Oncology2017. p. 663-71.

194. S JG, M MT, B HR, A K, R BD. Factors influencing treatment selection and 30-day mortality after chemotherapy for people with small-cell lung cancer: An analysis of national audit data. 2018. p. 176-83. 195. Paz-Ares LG, Perez JMT, Besse B, Moreno V, Lopez R, Sala MA, et al. Efficacy and safety profile of lurbinectedin in second-line SCLC patients: Results from a phase II single-agent trial. Journal of Clinical Oncology. 2019;37(15_suppl):8506-.

196. Antonia SJ, López-Martin JA, Bendell J, Ott PA, Taylor M, Eder JP, et al. Nivolumab alone and nivolumab plus ipilimumab in recurrent small-cell lung cancer (CheckMate 032): a multicentre, open-label, phase 1/2 trial. The Lancet Oncology. 2016;17(7):883-95. 